\title{
Chrystianizacja i romanizacja elit w rzymskiej Edessie
}

Edessa, zwana przez lokalną ludność Orhaj², była najważniejszym ośrodkiem krainy Osroene w północnej Mezopotamii rządzonej przez dynastię Abgarydów. Miasto to zachowało znaczną rangę także po włączeniu w struktury Cesarstwa Rzymskiego. Historia Edessy wyróżnia się różnorodnością zachowanych źródeł, do których należą zarówno wzmianki autorów zachodnich, jak i tradycja lokalna, uzupełniona przez niewielki zasób papirusów i inskrypcji. Dają one wgląd w kluczowe dla regionu procesy przemian kulturowych, uchwytne szczególnie od drugiej połowy II wieku po Chrystusie i trwające jeszcze długo po ostatecznej utracie niezależności około $242 \mathrm{roku}^{3}$. Dokumentują one coraz silniejsze zespolenie $\mathrm{z}$ administracją i kulturą Rzymu oraz postępującą chrystianizację, która zdefiniowała późnoantyczny wizerunek tego syryjskiego ośrodka.

Przekształcenie królestwa w prowincję nastąpiło w przypadku Osroene w niemal pokojowy sposób. Posiadamy co prawda wzmianki o dwóch epizodach zamieszek ${ }^{4}$, jednak po konflikcie na początku panowania

1 Daria Jędrzejewska, doktorantka w Pracowni Historii Bizancjum na Wydziale Historii Uniwersytetu im. Adama Mickiewicza w Poznaniu; e-mail: darolb@amu.edu.pl; ORCID: 0000-0001-9684-9743.

2 Była to nazwa aramejska, starsza od greckiej nadanej przez macedońskich kolonistów.

3 W sprawie prawdopodobnej data utraty tronu przez ostatniego Abgara, zob. S. Ross, Roman Edessa. Politics and culture on the eastern fringes of the Roman Empire, 114-242 CE, London 2001, s. 75. W kwestii szerszych okoliczności politycznych, por. P. Edwell, Between Rome and Persia: the middle Euphrates, Mesopotamia and Palmyra under Roman control, New York 2008.

4 Pierwsze po śmierci Abgara Wielkiego, drugie wspomniane są tylko przez Michała Starszego (Michael Syrus, Chronicon V 5, 77-78, tł. J.-B. Chabot, Chronique de Michel le Syrien, Patriarche Jacobite d'Antioche (1166-1199), t. 1, Paris 1899, s. 120) i być może znajdują odbicie w krótkich rządach ostatniego Abgara i tymczasowym po- 
Septymiusza Sewera Edessa nie wystąpiła już militarnie przeciw rzymskiej władzy. By scalić Osroene z Cesarstwem, zarówno Rzymianie, jak i współpracujący z nimi ostatni Abgarydzi musieli uzyskać poparcie grupy społecznej, której rola w podobnych procesach była kluczowa, czyli lokalnych elit. Ich rola została dostrzeżona przez badaczy regionu - już Judah Segal (Edessa, The Blessed City, London 1970, s. 21) użył dla otoczenia króla Edessy określenia „wolni ludzie” (free men) oraz stwierdził, że wielu z nich musiało współpracować z Rzymem i otrzymać obywatelstwo. W tym kontekście należy także przywołać książkę Stevena Rossa o romanizacji Edessy do 242 roku$^{5}$.

Co najmniej jeden ród używał nazwiska Aurelius już w latach siedemdziesiątych II wieku' ${ }^{6}$. Również w papirusach z połowy III wieku obecne są liczne rodzime imiona urzędników z rzymskim nomen gentile ${ }^{7}$,

rzuceniu rzymskich tytułów oraz statusu kolonii w papirusie znad Eufratu z 242 roku. J. Teixidor, Deux documents syriaques du III siècle après J.-C., provenant du Moyen Euphrate, „Comptes rendus des séances de l'Académie des Inscriptions et Belles-Lettres” 134/1 (1990) s. 144-166.

5 Por. Ross, Roman Edessa, s. 46-83. We wcześniejszym artykule (S. Ross, The Last King of Edessa: New Evidence from the Middle Euphrates, ZPE 97 (1993) s. 198) autor stwierdza: „Edessa had a local aristocracy ready and able to step in and assume leadership in the renewed colonia after Abgars' removal".

6 Według Michała Starszego (Syryjczyka). Michael Syrus, Chronicon V 5, 78, Chronique de Michel le Syrien, s. 120. Rzymianie po wygnaniu planującego rebelię króla Abgara ustanowili w jego miejsce namiestnika Aurelianusa syna Habesaia. W tym zniekształconym imieniu można rozpoznać Aureliusza Hafsaia z rodu od kilku pokoleń obecnego w elitach Edessy. Potwierdza to dokument DP 28, który dla 243 roku wymienia jako stratega Marka Aureliusza Abgara, syna Hafsaia. Niejaki Chapsai jest możnym na dworze króla Abgara w Nauce Addaja. Pierwszy Aureliusz Hafsai jest znany z inskrypcji z Sumatar Harabesi i uznaje się go za wczesnego przedstawiciela prorzymskiego stronnictwa z lat sześćdziesiątych I wieku po Chrystusie. Dzięki temu można powiedzieć z dużą dozą pewności, że po usunięciu króla najwyższe stanowisko otrzymał lokalny arystokrata z klanu od dawna przychylnego Rzymianom. Najpełniejsze omówienie tego wątku, zob. Ross, The Last King of Edessa, s. 191-193.

7 Była to praktyka częsta w pierwszych dziesięcioleciach po Constitutio Antoniniana, szczególnie w Azji Mniejszej i Syrii. Por. A. Blanco-Pérez, Nomenclature and Dating in Roman Asia Minor: (M.) Aurelius/a and the 3rd Century AD, ZPE 199 (2016) 271-293. W zachowanych rzymskich materiałach epigraficznych częściej występuje sam Aurelius, w Edessie natomiast dominuje forma Marcus Aurelius/Marcia Aurelia. Istnieje teza (za: D. Hagedorn, „Marci Aurelii” in Ägypten nach der Constitutio Antoniniana, „Bulletin of the American Society of Papyrologists” 16 (1979) s. 48), że Marci Aurelii to obywatele, którzy otrzymali tę godność przed Constitutio Antoniniana. Hagedorn (,Marci Aurelii”, s. 59) badający papirusy egipskie nie potwierdza tego, lecz zauważa wyższy sta- 
co świadczy o dalszym udziale lokalnej ludności w zarządzaniu Osroene ${ }^{8}$. Klasyczny model romanizacji, który zakłada dobrowolne przyjmowanie przez lokalne elity rzymskich wzorców kulturowych traktowanych jako prestiżowe ${ }^{9}$, wydaje się być tu dobrze uchwytny. Należy jednak zastanowić się, czy oznacza to, że wyższe warstwy Edessy zostały poddane podobnemu procesowi akulturacji, jak elity wcześniej podbitych ośrodków rzymskiego Wschodu ${ }^{10}$. Romanizacja Edessy nie prowadzi bowiem do odrzucenia własnej tożsamości, która w kolejnych wiekach wręcz rozkwita. Sytuacja jest tym szczególniejsza, że równolegle $\mathrm{z}$ ugruntowywaniem się rzymskiej władzy w regionie postępowała chrystianizacja zakorzeniona w rodzimej tradycji - jej legendarnym początkiem miało być nawrócenie króla Abgara i jego dworu.

Biorąc pod uwagę ważną rolę, jaką odgrywały lokalne elity w czasach królewskich i w pierwszych dziesięcioleciach integracji z Rzymem, zastanawiający jest fakt, że pojawiają się one bardzo rzadko w późniejszych źródłach dotyczących Osroene. Jaka była tego przyczyna? Czy edesseńska arystokracja została rzeczywiście wcześnie schrystianizowana i uczestniczyła w religijnym rozwoju miasta? Czy zanikła pod rzymską władzą, czy też zachowała pewną odrębność zwyczajów, która definiowała jej status $\mathrm{w}$ czasach królewskich? Wzmianki na ten temat są nieliczne, jednak pozwalają dojść do interesujących wniosków, które pragnę poniżej sformułować.

tus i pozycję społeczną osób tytułujących się Marci Aurelii. Tymczasem w Edessie przedstawiciel ważnego rodu o przydomku Hafsai, którego przodek tytułował się Aureliuszem już w latach siedemdziesiątych II wieku, nie używa imienia Marcus.

8 Papirus DP 28 znaleziony w Dura Europos, napisany w Edessie, daje interesujący wgląd w kwestię romanizacji miejscowej ludności w 243 roku. Marek Aurelius Antiochus syn Belszy, w którego rezydencji napisano dokument, nosi tytuł eques romanus, podobnie jak strateg Marek Aureliusz Abgar, syn Ma'nū, wnuk Aggi. Drugim strategiem jest Abgar syn Hafsaia, niewolnicę sprzedaje Marcja Aurelia, wnuczka Abgara, jej mężem jest Aureliusz Hafsai, syn Szamaszjabha, edesseńczyk z XII trybu. Występuje jeszcze kilka syryjskich imion z rzymskim nomen gentile, w tym Aureliusz Mannus, nadzorca świętych i miejskich archiwów. The Excavations at Dura-Europos Conducted by Yale University and the French Academy of Inscriptions and Letters. Final Report V, Part I. The Parchments and Papyri, red. C. Welles et al., New Haven 1959, s. 142-149.

9 W teorii Haverfielda i Milletta, patrz: J. Webster, Creolizing the Roman Provinces, „American Journal of Archaeology” 105/2 (2001) s. 213.

10 Zob. J.-B. Yon, La romanisation de Palmyre et des villes de l'Euphrate, „Annales. Histoire, Sciences Sociales" 59/2 (2004) s. 313-336; M. Konrad, The client kings of Emesa: a study of local identities in the Roman East, „Syria” 94 (2017) s. 261-295. 


\section{Elity Edessy w czasach panowania Abgarydów}

Jeszcze w II wieku po Chrystusie kraina Osroene była tradycyjnie związana z władcami partyjskimi, choć w trudnych warunkach politycznych elity szukały także porozumienia z Rzymem ${ }^{11}$. Trwałą współpracę przyniosła dopiero wyprawa Lucjusza Werusa, kiedy zawarto sojusz z przedstawicielem lokalnej dynastii w Edessie - jak wynika z inskrypcji w Sumatar Harabesi i danych numizmatycznych, około 165 roku prorzymski Abgar zastąpił propartyjskiego króla Waela ${ }^{12}$. Jego państwo pozostało jednak w dużej mierze niezależne. Gdy w 194 roku w Mezopotamii wybuchło antyrzymskie powstanie, Edessa sprzymierzyła się z wiernym Arsakidom Adiabene przeciw Nisibis. Mimo to gdy Septymiusz Sewer zdobył i podporządkował sobie Osroene, pozostawił króla Abgara VIII u władzy. W czasie wyprawy Sewera przeciw Partom Edessa była już lojalnym sojusznikiem cesarza. Panowanie Abgara VIII zwanego Wielkim zostało zapamiętane jako czas rozkwitu Edessy, mimo iż miasto musiało odbudować się po ciężkiej powodzi z 201 roku - lokalna kronika wymienia wśród zniszczonych wtedy budynków także kościół chrześcijan ${ }^{13}$.

Król zmarł prawdopodobnie w 212 roku. Jego następcą miał być kolejny Abgar, którego Karakalla uwięził w Rzymie. Miejscowe źródła wspominają o zamieszkach za panowania niegodziwego syna starego władcy. Jak wynika z emisji monetarnych, w 214 roku Edessa posiadała status kolonii i otrzymała nazwę Aurelia Antonina. Dynastia Abgarydów nie została jednak zupełnie usunięta. Lista edesseńskich władców mówi o 26-letnim panowaniu Ma ${ }^{e} \bar{u}$, syna Abgara ${ }^{14}$ - był to niewątpliwie znany z innych źródeł następca tronu o tytule paşgrībā, ojciec ostatniego króla Edessy ${ }^{15}$.

11 Najpełniejsze opracowanie: Ross, Roman Edessa. Patrz także klasyczna monografia J. Segala (Edessa, The Blessed City, London 1970).

12 Ross, Roman Edessa, s. 36.

13 Segal, Edessa, s. 13-15.

14 A. von Gudschmid, Untersuchungen über die Geschichte des Königreichs Osroëne, St. Petersbourg 1887, s. 6 (tł. listy królów: T. Nöldeke).

15 Paṣgrībā Ma nū wymieniany jest na inskrypcji jednej z dwóch kolumn stojących do dziś na cytadeli Edessy: „dla Šalmat, królowej, córki Ma“nū, pṣgryb”. As 1 (D27) The Old Syriac Inscriptions of Edessa and Osrhoene, Texts, Translations and Commentary, ed. H.J.W. Drijvers - J.F. Healey, Leiden 1999, s. 45-47. Także ostatnie słowo legendy na monetach Edessy (ABГAPO $\Sigma$ BA $\Sigma \mathrm{I} \Lambda \mathrm{EY} \Sigma$ MANNO $\Sigma$ ПAI $\Sigma$ ) było skrótem od pašgribā (D. Harnack, Partische Titel, vornehmlich in den Inschriften aus Hatra. Ein Beitrag zur Kentniss des parthischen Staates, w: Geschichte Mittelasiens in Altertum, red. F. Altheim - R. Stiehl, Berlin 1970, s. 516) i tytułem tego samego księcia Ma nū. Jest to syryjskie zapożyczenie ze średnioperskiego pasāgrīw (T. Gnolli, The Interplay of Roman and Iranian Titles in the Roman East, 1st-3rd Century A.D., Wien 2007, s. 115), podobnego w zna- 
Najwyraźniej nie otrzymał on królewskiej tiary, lecz zachował jakiś zakres władzy w Osroene. Enigmatyczne rządy ostatniego Abgara były potwierdzone tylko przez monety do czasu odkrycia papirusów znad Eufratu z lat czterdziestych III wieku' ${ }^{16}$. Ukazują one wyraźnie, że Abgar syn Ma 'nū był królem za panowania Gordiana i został usunięty (zmarł?) ok. 242 roku $^{17}$. Późny przekaz Michała Starszego (Syryjczyka) podaje, że królestwo Edessy zostało ostatecznie zlikwidowane w piątym roku panowania Filipa $(249)^{18}$, w świetle danych ze wspomnianych papirusów większość badaczy przyjmuje jednak wcześniejszą chronologię.

Ważnym aspektem tożsamości edesseńskich elit jest fakt, iż przez cały ten okres, mimo rosnącej zależności od Rzymu, ich kulturowym wzorcem pozostawał dwór partyjskiego króla królów. Do końca istnienia dynastii Abgarydzi nosili się na sposób irański, znakiem ich władzy zaś była przewiązana wstęgą diademu tiara. Rola tego atrybutu znajduje potwierdzenie zarówno w ikonografii, jak i w źródłach pisanych - w Nauce Addaja ${ }^{19}$ Aggai, który tworzył tiary, odmawia jej wykonania dla nowego władcy po śmierci Abgara Wielkiego ${ }^{20}$. Jeszcze na monetach wybijanych za panowania Gordiana stojący przed cesarzem ostatni król Edessy występuje w orientalnym stroju - tiarze, tunice i szerokich spodniach, z długim mieczem u lewego boku. Podobny ubiór nosili także arystokraci przedstawieni na licznie zachowanych mozaikach grobowych oraz posągach tego okresu. Chrześcijanin z Palestyny i grecki pisarz Juliusz Afrykański, który odwiedził Edessę za panowania Abgara Wielkiego, podaje kilka informacji o rozrywkach praktykowanych na dworze tego władcy ${ }^{21}$. Był świadkiem, jak królewski syn Mannos (Ma'nū) powalił na polowaniu dzika i jak arystokrata Bar Daisan chwalił się umiejętnościami strzelania z łuku. Były to

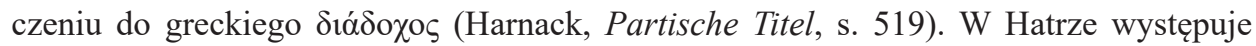
w ośmiu inskrypcjach w kilku nieco różniących się wersjach i odnosi się do dwóch książąt o imieniu Abdsamia: pierwszy był synem Sanatruka I, kolejny - niedoszłym królem Hatry, następcą Sanatruka II (Gnolli, The Interplay of Roman and Iranian Titles, s. 116117). Użycie tego tytułu w Edessie potwierdza wpływy irańskie w dynastii Abgarydów, a także podobieństwo zwyczajów rodziny panującej Hatry.

16 Teixidor, Deux documents syriaques du III siècle après J.-C., provenant du Moyen Euphrate, s. 144-166.

17 Więcej na ten temat: Ross, The Last King of Edessa; Ross, Roman Edessa, s. 73-82.

18 Ross, The Last King of Edessa, s. 191; Michael Syrus, Chronicon V 5, 77-78, s. 120.

19 Tytuł za polskim przekładem: W. Witakowski, Nauka Apostoła Addaja: wstep, przekład z języka syryjskiego, komentarz, STV 22/2 (1984) s. 181-213.

20 Doctrina Addai 49, tł. G. Howard, The Teaching of Addai, Text and Translation, Ann Arbor 1981, s. 103.

21 Julius Africanus, Cesti F12.20.25-59 (Cestus 7), tł. W. Adler, Cesti. The Exant Fragments, Berlin - Boston 2012, s. 101-103. 
typowe zajęcia wyższych sfer irańskich, które najwyraźniej zastępowały w Edessie helleńskie wychowanie jeszcze pod koniec II wieku ${ }^{22}$.

Przekaz Juliusza Afrykańskiego jest cenny ze względu na swoją wiarygodność - to jedyna zachowana bezpośrednia relacja z dworu króla Abgara. Wspomniany wyżej Bar Daisan był postacią niezwykle ciekawą i ważnym przedstawicielem arystokracji Edessy. Z innych źródeł wiemy, że on sam lub jego rodzice przybyli ze wchodu (bywał nazywany Partem), lecz wychował się razem z królem Abgarem, został później mędrcem i, co ważne, chrześcijaninem przez kolejne pokolenia coraz silniej oskarżanym o herezję. Zachowała się spisana przez jego ucznia Księga Praw Krain ${ }^{23}$ - traktat omawiający wpływ fatum na losy człowieka, opisujący w tym kontekście zwyczaje ludów Wschodu i Zachodu świata z perspektywy rzymsko-irańskiego pogranicza.

Jednak najpełniejszym opisem dworu króla Edessy pozostaje Doctrina Addai, w polskim przekładzie Witolda Witakowskiego znana jako Nauka Apostoła Addaja. Ten syryjski tekst zachowany jest w wersji z V wieku, czerpie jednak z dużo wcześniejszej tradycji i przedstawia początki chrześcijaństwa w Edessie wkrótce po śmierci Chrystusa ${ }^{24}$. Dotknięty chorobą król Abgar Ukkama (Czarny) miał wysłać posła Channana ${ }^{25}$ do Jerozolimy i uzyskać od samego Jezusa obietnicę uleczenia oraz wyjątkowe słowa błogosławieństwa i ochrony przed wrogami dla Edessy. Później na dwór Abgara przybywa apostoł Addaj, który uzdrawia króla i nawraca na chrześcijaństwo elity, następnie także pozostałych mieszkańców.

Nauka Addaja mimo późnego czasu powstania zaskakująco trafnie opisuje edesseńskie elity okresu królewskiego, określa stanowiska i hierarchię możnych. Channan, wyprawiony jako poseł, pełnił też funkcję za-

22 Segal (Edessa, s. 31) uważa, że możni Edessy wysyłali swoich synów na wykształcenie do cesarstwa Rzymskiego już w czasach królewskich. Może to potwierdzać Hymn o Perle, jeśli rzeczywiście powstał w Edessie (Hymnus Margaritae, The Hymn of the Pearl. The Syriac and Greek Texts with Introduction, Translations and Notes, ed. J. Ferreira, Sydney 2002). Są to jednak tylko domysły - żadne wiarygodne źródło, ani ze strony edesseńskiej, ani rzymskiej, nie przekazuje takiego obrazu.

23 Bardesanes, Liber Legum Regionum, tł. H.J.W. Drijvers, The Book of the Laws of Countries. Dialogue on Fate of Bardaisan of Edessa, Piscataway 2006.

24 Według J.W. Drijversa (The Protonike Legend, the Doctrina Addai and Bishop Rabbula of Edessa, VigCh 51/3 (1997) s. 301-302) Nauka Addaja mogła powstać w końcu III wieku, ostateczny kształt zaś osiągnęła po dodaniu kolejnych elementów w V wieku. Podobnie S. Brock (Eusebius and Syriac Christianity, w: Eusebius, Christianity, and Judaism, red. H.W. Attridge - G. Hata, Detroit 1992, s. 227) zauważa zbieżność z Addą, misjonarzem Maniego.

25 Polska wersja imion za: Witakowski, Nauka Apostoła Addaja. 
rządcy archiwum ${ }^{26}$. Abdu syn Abdu był jednym z tych, którzy „siedzą ze skrzyżowanymi nogami" przed Abgarem, czyli członkiem rady ${ }^{27}$. Gdy całe miasto zebrało się, by słuchać nauk Addaja na rozkaz króla, przybyli również liczni wymienieni z imienia dostojnicy (Awida, Lebbu, Chafsaj, Bar Kalba, Labbuna, Szamszygram), a także „inni podobni im możnowładcy, dygnitarze królewscy, dowódcy, wszyscy żołnierze" 28 . Z nich Awida i Bar Kalba, „książęta i dowódcy”, posiadali królewskie diademy ${ }^{29}$. Gdy Addaj umarł, miał zostać pochowany w bogato zdobionym grobowcu królewskim rodu Arju, opłakiwał go zaś sam Abgar „wraz z dostojnikami swego królestwa" ${ }^{30}$. Nauka Addaja twierdzi, że dokumenty o tych wydarzeniach zostały złożone w archiwum, gdzie zbierano zapisy wszystkiego, co wypowiedziano przed królem, oraz wszelkie rozkazy i statuty ${ }^{31}$. Archiwum w Edessie zostało później przejęte przez rzymską administrację i w III wieku, jak poświadczają papirusy, składano tam także akta kupna i sprzedaży ${ }^{32}$.

$\mathrm{O}$ ile treść dokumentu jest niewątpliwie apokryficzna, wydaje się, że realia królewskiego dworu odpowiadają nie tyle epoce Abgara Ukkamy z pierwszego wieku po Chrystusie, lecz Abgara Wielkiego ${ }^{33}$. Dwór króla Edessy w Nauce Addaja jest przedstawiony w sposób spójny i wiarygodny, z godnym uwagi zrozumieniem panujących na nim praw i zwyczajów. Jest prawdopodobne, iż autor Nauki Addaja korzystał z zasobów archiwów Edessy, wymienieni w niej możni zaś są postaciami autentycznymi. Co więcej, obraz królewskiego dworu, jaki wyłania się z Nauki Addaja, współgra z tym, co wiemy o elitach innych podobnych do Osroene ośrodków przełomu II i III wieku po Chrystusie. Przede wszystkim należy tu przywołać inskrypcje i posągi z Hatry, gdzie rządziła lokalna dynastia pochodzenia arabskiego, oraz przekazy o dworze Arsakidów z Armenii i z samego Iranu ${ }^{34}$.

26 Doctrina Addai 3, tł. Howard, The Teaching of Addai, s. 3.

27 Doctrina Addai 6, tt. Howard, The Teaching of Addai, s. 3.

28 Doctrina Addai 18 (cyt. za: Witakowski, Nauka Apostoła Addaja, s. 194).

29 Doctrina Addai 17-18 (cyt. za: Witakowski, Nauka Apostoła Addaja, s. 202-203).

30 Doctrina Addai 46 (cyt. za: Witakowski, Nauka Apostoła Addaja, s. 211).

31 Doctrina Addai 50, tł. Howard, The Teaching of Addai, s. 105-106.

32 Jak poświadcza papirus DP 28 z Dura Europos, jedna kopia kontraktu składana była w miejskich archiwach już pod rzymską władzą, druga pozostawała w posiadaniu nabywcy. Zob. C. Welles et al., The Excavations at Dura-Europos, The Parchments and Papyri, s. 142-149.

33 S. Brock (Eusebius and Syriac Christianity, s. 227) wątpi w fakt konwersji Abgara Wielkiego.

34 Najszerszych danych dostarcza ikonografia: posągi i inne przedstawienia lokalnych elit, ich strój i uzbrojenie będące przedmiotem badań Sylvii Winkelmann. Zob. 
Z Nauki Addaja, ale i z wzmianek u Juliusza Afrykańskiego wynika, że elity Edessy u progu rzymskiego panowania były wyraźnie ukształtowane. Trzon stanowiła lokalna arystokracja: członkowie rodziny panującej, doradcy króla, dowódcy straży, wyżsi urzędnicy dworscy i przedstawiciele bogatych rodów. Ich zwyczaje były silnie przesiąknięte kulturą irańską̧, wzajemne związki zaś cementowało wspólne wychowanie na dworze króla i uczestnictwo w aktywnościach charakterystycznych dla orientalnych dworów, do których należały polowania i strzelanie $\mathrm{z}$ łuku ${ }^{36}$.

\section{Arystokracja chrześcijańska? ${ }^{37}$}

Nawet jeśli przyjmiemy, że realia Nauki Apostoła Addaja odpowiadają przełomowi II i III wieku po Chrystusie, wiarygodność tego przekazu w kwestii konwersji króla Abgara i jego dworu na chrześcijaństwo (w tej wersji byłby to Abgar Wielki, nie Ukkama) pozostaje przedmiotem wielu

S. Winkelmann, Katalog der parthischen Waffen und Waffenträger aus Hatra, Halle 2004; S. Winkelmann, Waffen und Wafferträger auf Partischen Münzen, „Parthica” 8 (2006) s. 131-152; S. Winkelmann, Partherzeitliche Waffenträger in Edessa und Umgebung, w: Edessa in hellenistisch-römischer Zeit: Religion, Kultur und Politik zwischen Ost und West; Beiträge des Internationalen Edessa-Symposiums in Halle an der Saale, 14. - 17. Juli 2005, red. J. Tubach - C. Rammelt - L. Greisiger, Würzburg 2009.

35 Tego ważnego aspektu wydaje się nie dostrzegać S. Ross (Roman Edessa, s. 116), który konsekwentnie unika określenia „irański” wobec edesseńskich elit. Warstwa ta według niego uległa daleko posuniętej romanizacji i hellenizacji, mimo iż Edessa pozostała przez wiele lat miastem „mezopotamskim”.

36 W Persji zwyczaje te przetrwały do epoki sasanidzkiej. Jeszcze na dworze Chosroesa II Mar Qardagh późniejszy męczennik „has proven his excellence in three of the most cherished pursuits of the Sasanian Aristocracy - archery, polo and hunt" (J. Walker, The Legend of Mar Qardagh: Narrative and Christian Heroism in Late Antique Iraq, Berkeley 2006, s. 121).

37 Omawiając kwestię chrześcijaństwa i edesseńskiej arystokracji, nie sposób nie wspomnieć artykułu W. Adlera przywołującego owo zagadnienie już w tytule (The Kingdom of Edessa and the Creation of a Christian Aristocracy, w: Jews, Christians and the Roman Empire. The Poetics of Power in Late Antiquity, red. N.B. Dorhman A. Yoshiko Reed, Philadephia 2013, s. 43-62). Tezy w nim zawarte są jednak ryzykowne. Autor skupia się na postaci Bar Daisana i, co mocno zaskakujące, Juliusza Afrykańskiego, uznając go na podstawie pobytu w Edessie za „Palestinian Christian, edessene courtier" (Adler, The Kingdom of Edessa and the Creation of a Christian Aristocracy, s. 60). Tymczasem Juliusz Afrykański jest raczej tylko gościem i obserwatorem na dworze Abgara. Treść Nauki Addaja nie jest w ogóle przywoływana. 
polemik $^{38}$. Jeśli chodzi o samego władcę, tezę tę może potwierdzać jedynie określenie króla jako ,świętego męża” u Juliusza Afrykańskiego oraz wzmianka o „dojściu do wiary” Abgara w Księdze Praw Krain ${ }^{39}$. Ta ostatnia jest uważana przez część badaczy za interpolację ze względu na brak tych słów u Euzebiusza z Cezarei - opisuje on zakaz kastracji wydany przez króla Abgara w kontekście podporzędkowania się raczej rzymskim niż chrześcijańskim prawom ${ }^{40}$. Brakuje też chrześcijańskiej symboliki w grobach edesseńskich możnych, mozaikach i posągach III wieku ${ }^{41}$. Należy jednak zaznaczyć, że chrześcijanie Mezopotamii nie zostawili jeszcze w tym wczesnym okresie śladu w kulturze, w której wzrastali. Jak dowodzą akta męczenników perskich, jeszcze w IV wieku możni na dworze króla Szapura II - między innymi wpływowy potomek Rzymian, Pusaj praktykowali chrześcijaństwo $\mathrm{w}$ ukryciu, podczas gdy irańscy towarzysze uważali ich za wyznawców zoroastryzmu ${ }^{42}$. Na ten sam problem zwraca uwagę Afrahat, który oskarża wręcz wiernych z Ktezyfontu o kolaborację $\mathrm{z}$ władzą ${ }^{43}$. Nie rozpoznalibyśmy chrześcijanina w dostojniku Bar Daisanie z opisu Juliusza Afrykańskiego, dlatego też nie należy całkowicie odrzucać możliwości nawrócenia się króla Abgara. Sytuacja, w której władca nieoczekiwanie przyjmuje inną wiarę, nie byłaby wyjątkiem w starożytnym świecie. Stulecie później miał miejsce lepiej udokumentowany przypadek konwersji arsakidzkiego króla w Armenii, wreszcie wcale nieoczywisty przykład rzymskiego cesarza Konstantyna, który ochrzcił się na łożu śmierci ${ }^{44}$.

38 Por. Brock, Eusebius and Syriac Christianity, s. 221. Dwa główne stanowiska badaczy zostały zapoczątkowane przez F. Burkitta (nawrócił się Abgar Wielki, lecz legenda została dopasowana do czasów Jezusa, gdy panował Abgar Ukkama) oraz W. Bauera (legenda nie jest odbiciem autentycznych wydarzeń z czasów królewskich). Oba obozy zgadzają się, że pierwsza wersja Nauki Addaja powstała najwcześniej ok. 300 roku.

39 Bardesanes, Liber Legum Regionum, t1. Drijvers, The Book of the Laws of Countries, s. 59: ,what shall we say of the new people of us Christians, that the Messiah has caused to arise in every place and in all climates".

40 Eusebius Caesariensis, Praeparatio Evangelica VI 10, 44, tł. E.H. Gifford, Evangelicae Praeparationis Libri XV, London 1903, s. 189; Brock, Eusebius and Syriac Christianity, s. 223.

${ }^{41}$ Od 2015 roku odkrywane są kolejne starożytne grobowce na przedmieściach Edessy i nowe struktury w samej Cytadeli, co może powiększyć zasób źródeł.

42 Acta Martyrum Persarum: Acta S. Pusai, w: Ausgewählte Akten Persischer Märtyrer, red. O. Braun, Kempten - München 1915, s. 64.

43 A. Uciecha, Watkipolemiczne wpismach Afrahataiśw. Efrema, w: Chrześcijaństwo antyczne, red. J. Drabina, Kraków 2006, s. 117.

44 K. Ilski, Chrzest Konstantyna Wielkiego, w: Teologia i liturgia chrztu od starożytności chrześcijańskiej do czasów nowożytnych, red. A. Wyrwa - J. Górecki, Poznań 2015, s. 148. 
Najczytelniejszym dowodem na istnienie wpływów chrześcijaństwa na dworze Abgara Wielkiego pozostaje postać Bar Daisana, bliskiego towarzysza króla. Bar Daisan nigdy nie był ukazywany w roli ,apostoła" Edessy, jednak niezależnie od tego, czy uznamy go za Euzebiuszem z Cezarei za nawróconego z herezji czy też wzorem późniejszych pisarzy kościelnych - za chrześcijanina, który w herezję popadł, źródła zgadzają się co do faktu, że miał on naśladowców. Można podejrzewać, że należeli do nich ludzie z kręgów Bar Daisana, czyli z elit Edessy. Także poświadczeni w Księdze Praw Krain jego uczniowie byli dobrze wykształconymi, bogatymi młodymi ludźmi. Wzmianki o elitach Edessy oraz naukach Bar Daisana zazębiają się w interesujący sposób w późniejszej historii miasta, chociaż sami przedstawiciele lokalnej arystokracji są wspominani niezwykle rzadko. Interesujący jest również fakt, że poza Nauka Addaja żadne źródło dotyczące Edessy nie podkreśla chrześcijańskości jej elit. Kwestia ta jest traktowana bardzo oględnie, mimo iż samo miasto zdobywa sobie miano błogosławionego i wiernego Bogu.

\section{Tradycja akt Szmony, Gurii i Ḥabbiba}

Druga połowa III wieku po Chrystusie to jeden z najuboższych w źródła okresów w dziejach miasta. Wiadomo jednak, że chrześcijan Edessy nie ominęły wówczas prześladowania, które zostały opisane w Aktach Szmony $i$ Gurii oraz w Aktach Habbiba przez niejakiego Teofilusa w pierwszej połowie IV wieku. Szmona, Guria i Habbib stali się w tradycji Edessy jej najważniejszymi męczennikami, miejsce ich śmierci zaś zostało zamienione w sławne martyrium. Należy nadmienić, że z Edessy znane są także akta Szarbela, które mają opisywać prześladowania z czasów Trajana, są one jednak najprawdopodobniej fikcyjne ${ }^{45}$. W przypadku Szmony i Gurii wzmianki wykraczające poza zwyczajowy schemat akt i brak egzaltacji w opisach męczeństwa świadczą na korzyść ich autentyczności ${ }^{46}$.

W aktach Szmony i Gurii w sposób oczywisty zaznaczona jest obecność sprawców prześladowań - pogańskich Rzymian. „W czternastym roku panowania Dioklecjana" ${ }^{" 47}$ w Edessie stacjonują rzymscy żołnierze. Miastem rządzi namiestnik Mysianus utrzymujący ścisłe kontakty z Antiochią ${ }^{48}$, jed-

45 Brock, Eusebius and Syriac Christianity, s. 223.

46 Przyjęta powszechnie propozycja F. Burkitta. Zob. Martyrium SS. Guriae, Samonae et Abibi, t1. F. Burkitt, Euphemia and the Goth, London 1913.

47 Shmona 1, tł. Burkitt, s. 90: ,and that is in the $14^{\text {th }}$ year of the reign of Diocletian".

48 Shmona 6; 16, tł. Burkitt, s. 92, 94. 
nak niższymi urzędnikami są nieznani z innych źródeł Abgar syn Zoºry i Abba - uwagę zwracają ich rodzime imiona ${ }^{49}$. Szmona i Guria nie pochodzili z samego miasta, lecz z okolicznych wiosek, gdzie chrześcijaństwo było już rozprzestrzenione ${ }^{50}$. Zostali uwięzieni za swoją aktywność $\mathrm{z}$,wieloma innymi" ${ }^{51}$, lecz w ich pogrzebie mógł uczestniczyć tłum ludzi, najwyraźniej nienękany przez Rzymian. Mieszkańcy Edessy przynoszą cenne szaty i wonności, by okryć ciała zmarłych i składają ich w jednej trumnie, która znalazła się potem w martyrium ${ }^{52}$. Autor akt - Teofilus - pisze, że Szmona i Guria wyrzekli się spuścizny pogaństwa swoich ojców ${ }^{53}$, $\mathrm{w}$ innym miejscu używa tego określenia wobec siebie samego ${ }^{54}$. Są to ciekawe wzmianki. Często zwracano uwagę na to, czy ktoś pochodził z już chrześcijańskiej rodziny (jak wspomniany wyżej Pusaj w Persji) czy też był neofitą. Chrystianizacja Osroene dopiero więc postępowała, pokolenie połowy III wieku zaś musiało być w przeważającej mierze pogańskie, co nie potwierdza przekazu Nauki Apostoła Addaja o przejściu na nową wiarę całego miasta.

Niewiele więcej informacji podają akta Habbiba oprócz tego, że prześladowania w Edessie trwały długo - jeszcze za panowania Licyniusza (po 313 roku). Habbib również nie pochodził z Edessy, lecz z wioski Tel-șhe ${ }^{55}$. Jego działalność rzuca światło na chrystianizację regionu - Habbib odwiedza kościoły w wioskach i potajemnie czyta pisma. Edessa jest określona jako twierdza, w której rezyduje namiestnik Auzoniusz. Ma on na prowincji informatorów, którzy donoszą o zachowaniu Habbiba ${ }^{56}$, co może odzwierciedlać rzeczywiste próby rzymskiego przeciwdziałania rozpowszechnianiu się chrześcijaństwa w Osroene. Jedyna wzmianka o przedstawicielu wyższych sfer dotyczy założyciela cmentarza, Abszelama syna Abgara ${ }^{57}$.

Akta Szmony, Gurii i Habbiba marginesowo potwierdzają dalsze istnienie lokalnej arystokracji, a także zachowanie przez nią ważnych stanowisk w rzymskiej administracji. Jej przedstawiciele w ogóle jednak nie uczestniczą w narracji, nie są też w żaden sposób przywołani w kontekście krzewienia się chrześcijaństwa. Przyczyn może być kilka: elity miasta po-

\footnotetext{
49 Shmona 1, tł. Burkitt, s. 90.

50 Shmona 3, tł. Burkitt, s. 91.

51 Shmona 4, tł. Burkitt, s. 91.

52 Shmona 66-67, t1. Burkitt, s. 107-108.

53 Shmona 69, tł. Burkitt, s. 109. W tłumaczeniu Burkitta: ,who renounced the evil inheritance of the paganism of their fathers".

54 Habbib 40, s. 127.

55 Habbib 1-2, s. 112.

56 Habbib 3, s. 113. W thumaczeniu Burkitta: „The city Informers”.

57 Habbib 35, s. 124-125.
} 
zostawały wówczas pogańskie, podporządkowały się nakazowi złożenia ofiar, rzymska administracja nie objęła ich represjami lub też zamiarem autora akt Szmony i Gurii nie było podkreślanie ich roli. Do tej ostatniej opcji przychyla się Sebastian Brock (Eusebius and Syriac Christianity, s. 228), który widzi w postaciach Szmony, Gurii i Habbiba „kamienie węgielne” innej tradycji niż ta obecna w Nauce Addaja: męczennicy pochodzili spoza miasta i akta wydają się sugerować, że właśnie okoliczne wioski, nie Edessa, były ośrodkami najintensywniejszej chrystianizacji. Niemniej należy zaznaczyć, że cała spuścizna męczeństwa Szmony i Gurii - święte martyrium, cuda dokonane za ich wstawiennictwem - jest już nierozerwalnie związana z samą Edessą, nie z wioskami, z których mieli oni pochodzić. Mówiąc dzisiejszym językiem, Szmona, Guria i Ḥabbib stali się patronami Edessy.

\section{Euzebiusz z Cezarei i Euzebiusz z Emesy}

Po raz pierwszy w rzymskim świecie rozsławił Edessę Euzebiusz z Cezarei, który w swojej Historii Kościelnej przytoczył list Jezusa do króla Abgara i ukazał miasto w bardzo pochlebny sposób ${ }^{58}$ : oto sam Chrystus miał uznać króla Edessy za godnego, by odpowiedzieć na jego prośbę i uzdrowić go ${ }^{59}$. Jak twierdzi Euzebiusz, „od tego czasu aż do teraz” całe miasto edesseńczyków pozostało oddane imieniu Chrystusa ${ }^{60}$. Jest to najwcześniejsze zewnętrzne źródło, które - dość nieoczekiwanie - ukazuje Edessę jako wybitnie chrześcijańskie miasto.

Po raz pierwszy także poświadczone jest istnienie tradycji nawrócenia króla w szerszej wersji zachowane w Nauce Apostoła Addaja. Pojawia się tu pytanie, czy Euzebiusz z Cezarei streszcza pełniejszy opis, pomijając szczegóły nieistotne dla czytelnika greckiego, czy też tradycja Nauki Addaja w wersji z IV wieku nie zawierała jeszcze elementów dodanych później. Dla niniejszego wywodu istotny jest jeden aspekt tego problemu - Euzebiusz skupia się na nawróceniu króla Abgara, Nauka Apostoła Addaja dużo więcej uwagi poświęca także edesseńskim elitom. Jednak i u Euzebiusza obecność możnych jest zaznaczona (I 13, 13 - gdy nadchodzi „Tadeusz”, odpowiednik Addaja, możni są obecni i stoją przy królu; I 13, 17 - Abdu syn Abdu zostaje uleczony; Euzebiusz nie określa rangi

58 Eusebius Caesariensis, Historia Ecclesiastica I 13, 2, tł. A. Caba, Euzebiusz z Cezarei, Historia kościelna, Poznań 2013, s. 67.

59 Eusebius Caesariensis, Historia Ecclesiastica I 13, 3, tt. A. Caba, s. 67.

60 Eusebius Caesariensis, Historia Ecclesiastica II 1, 7, tł. A. Caba, s. 81. 
tego człowieka, w Nauce Addaja jest on jednym z najważniejszych możnych). Przekaz Euzebiusza, szczegółowy w początkowych akapitach dotyczących kontaktu Abgara z Jezusem, w opisie aktywności „Tadeusza” jest względem Nauk Addaja bardzo lakoniczny i zapewne źródło, z którego korzystał, obszerniej opisywało scenę nauczania i reakcję mieszkańców. Skąd jednak pochodziło źródło Euzebiusza z Cezarei i w jaki sposób mógł on zainteresować się tym tematem? Edessa była wówczas niezbyt istotnym miastem, niewsławionym jeszcze obroną przed atakami Szapura II. Wątpliwe, by legenda o uzdrowieniu jej króla była już rozpowszechniona na rzymskim Wschodzie. Co więcej, Euzebiusz twierdzi, że miał dostęp do przetłumaczonych dokumentów z archiwum Edessy ${ }^{61}$.

W tym kontekście należy przywołać postać innego Euzebiusza, późniejszego biskupa Emesy, który działał w pierwszej połowie IV wieku po Chrystusie. Jego postać jest wciąż słabo zbadana, lecz nawet dość skąpe informacje, jakie przekazują o nim starożytni historycy, są arcyciekawe. Warto przytoczyć ustęp u Sokratesa Scholastyka ${ }^{62}$, który pisał za Jerzym z Laodycei:

Powiada bowiem w napisanej przez siebie biografii Euzebiusza, że pochodził on [Euzebiusz] z arystokratycznego rodu miasta Edessy w Mezopotamii; od lat chłopięcych uczył się Pisma Świętego; później otrzymał wykształcenie helleńskie od przebywającego w tym czasie w Edessie nauczyciela; na koniec Pismo Święte thumaczył mu Patrofil i Euzebiusz, z których jeden stał na czele Kościoła w Cezarei, drugi zaś w Scytopolis.

Z przekazu Sokratesa wynika, że Euzebiusz był wychowanym w chrześcijaństwie przedstawicielem lokalnej arystokracji edesseńskiej. Co więcej, jego pochodzenie potwierdza fakt, że część elit (z pokolenia rodziców Euzebiusza) wyznawała chrześcijaństwo już w II połowie III wieku

61 Eusebius Caesariensis, Historia Ecclesiastica I 13, 5, tł. A. Caba, s. 67: „Mamy pisemne świadectwo tych zdarzeń pochodzące z archiwów Edessy [...] będzie jednak najlpiej posłuchać samych listów wyjętych z archiwów i dosłownie przetłumaczonych z języka syryjskiego"; Eusebius Caesariensis, Historia Ecclesiastica I 13, 22, tł. A. Caba, s. 73: „Ufam, że nie bez pożytku przytoczyłem tutaj dosłownie to tłumaczenie z języka syryjskiego".

62 Socrates Scholasticus, Historia Ecclesiastica II 9, tł. S.J. Kazikowski, Sokrates Scholastyk. Historia Kościoła, Warszawa 1986, s. 163-164. Podobnie: Sozomenos, Historia Ecclesiastica III 6, tł. S. Kazikowski, Hermiasz Sozomen, Historia Kościoła, Warszawa 1989, s. 158-161; Robert Winn (Eusebius of Emesa. Church and Theology in the Mid-Fourth Century, Washington 2011, s. 1 oraz 21-25) sądzi, że Euzebiusz móg1 pochodzić od uczniów Paluta. 
po Chrystusie, czyli w okresie prześladowań, w których zgładzeni zostali Szmona i Guria. Młody Euzebiusz miał uczyć się u Euzebiusza z Cezarei i wydaje się bardzo prawdopodobne, że to on zainteresował swego mentora Edessą i przekazał treść legendy o nawróceniu Abgara.

Intrygujący jest fakt, że Euzebiusz z Cezarei mógł pochwalić się także sporą wiedzą o Bar Daisanie, którego opisuje w pochlebny sposób. Kilkukrotnie chwali jego mądrość, chociaż zauważa, że ów „nie do końca zmył z siebie piętno herezji" ${ }^{63}$, zna też treść Księgi Praw Krain, którą przytacza niemal dosłownie ${ }^{64}$. Jest bardzo możliwe, że również tu widoczny jest wpływ Euzebiusza emeseńskiego. Można zastanowić się, czy wyjątkowo pozytywne przedstawienie postaci Bar Daisana u historyka z Cezarei nie jest odbiciem poglądów późniejszego biskupa Emesy.

Euzebiusz emeseński jest pierwszym przedstawicielem elit Edessy od czasów Abgara Wielkiego, o którym posiadamy więcej informacji i warto poszukać w jego działalności ewentualnej spuścizny, jaką mógł wynieść $\mathrm{z}$ rodzinnego miasta. Inaczej niż przed wiekiem edesseńskie elity w czasach Euzebiusza kształciły swoich synów w duchu paidei. Ciekawą wskazówką jest informacja również przekazana przez Sokratesa Scholastyka, iż biskup Emesy miał towarzyszyć Konstantynowi II w wyprawie przeciw Persom $^{65}$. Ze względu na swe pochodzenie Euzebiusz emeseński mógł posiadać znaczącą wiedzę o kulturze czy nawet języku Iranu - pozostaje to jednak w ramach spekulacji. Najbardziej intrygujące są jednak powiązania Euzebiusza z nauką Bar Daisana.

Autor biografii Euzebiusza, Robert Winn (Eusebius of Emesa, s. 29) stwierdza, że podobieństwa w wykształceniu nie świadczą o tym, by Euzebiusz był od Bar Daisana zależny. Ze źródeł zdaje się jednak wynikać coś wręcz przeciwnego. Tak jak Bar Daisan, Euzebiusz emeseński był aktywnym przeciwnikiem marcjonitów i manichejczyków ${ }^{66}$. Zaraz po tym, gdy został wybrany biskupem Emesy, mieszkańcy oskarżyli go o przywiązanie do astrologii ${ }^{67}$. Był to zarzut poważny, który przyczynił się do niepowodzeń biskupa w działalności na tamtym terenie. Sama Emesa, syryjskie miasto, miała długą tradycję przywiązania do kultów solarnych i badań nieba. Tamtejsi gorliwi chrześcijanie musieli być szczególnie wyczuleni na podobne praktyki. W pogańskiej Edessie astralne kulty były również

63 Eusebius Caesariensis, Historia Ecclesiastica IV 30, 1-3, tł. Caba, s. 289.

64 Eusebius Caesariensis, Praeparatio Evangelica VI 10, tł. Gifford, s. 185-189.

65 Winn, Eusebius of Emesa, s. 2; Socrates Scholasticus, Historia Ecclesiastica II 9, tł. Kazikowski, s. 164.

66 Winn, Eusebius of Emesa, 26-28.

67 Winn, Eusebius of Emesa, s. 42; Socrates Scholasticus, Historia Ecclesiastica II 9, 8, tł. Kazikowski, s. 164. 
rozpowszechnione, jednak cała Księga Praw Krain stara się umieścić pochodzące z gwiazd fatum w ramach chrześcijaństwa, inne źródła zaś często podkreślają fakt studiów Bar Daisana nad astrologią. Zachowane kazania Euzebiusza emeseńskiego nie są jeszcze dobrze opracowane. Opisy naturalnego świata i jego hierarchii względem Boga wydają się być w interesujący sposób zbieżne z treścią Księgi Praw Krain i z pewnością aspekt ten warty jest dalszych badań i szerszej uwagi w świecie naukowym.

Euzebiusz z Cezarei poznał i opisał dwie ważne tradycje wywodzące się z Edessy, w tym „dokumenty” o nawróceniu jej władcy oraz naukę Bar Daisana. Jeśli uznamy rolę Euzebiusza emeseńskiego w ich przekazaniu, widać jeszcze wyraźniej, że te dwie tradycje nawiązujące do czasów przedrzymskiej niezależności dotyczą kręgu wyższych sfer Edessy oraz przechowywane były przez elity miasta. Bardzo istotne jest, że biskup Cezarei nie uważa treści nauk Bar Daisana i przytoczonej przez siebie Księgi Praw Krain za groźne dla ortodoksji. Miało się to zmienić w następnych dziesięcioleciach, gdy za heretyckie uznano nie tylko dzieła Bar Daisana, ale i jego następców. Co więcej, wzmianki o elitach miasta pojawiają się zastanawiająco często w kontekście walki z sektą bardesanitów.

\section{Elity miasta i bardesanici w czasach Efrema i Rabbuli}

O tym, że wyznawcy Bar Daisana rozwijali się w Edessie prężnie, najlepiej świadczy działalność Efrema z Nisibis w latach 363-373 i ostre, zaciekłe słowa, z jakimi zwalczał on tego mędrca. Nie była to polemika z martwą nauką, lecz z wciąż rozkrzewionym w Edessie wyznaniem. Efrem, chociaż sam pochodził z bogatej i być może pogańskiej rodziny z Nisibis, silnie dystansował się od ziemskiego życia i jego pokus - znał jednak dobrze żywot i poglądy Bar Daisana. W jednym z hymnów czyni aluzję do jego ziemskiego bogactwa, przywołując bogate szaty i szlachetne kamienie ${ }^{68}$, co ówczesnym musiało kojarzyć się z charakterystycznym strojem orientalnych arystokratów, być może wciąż noszonym przez elity miasta. Mimo wysiłków Efrema zwalczane przez niego teorie były bardzo kuszące. Jego uczniowie Paulonas i Aranad mieli stać się heretykami. Liber de Scriptoribus Ecclesiasticus z drugiej połowy V wieku wymienia zapewne identycznego z powyższym Paulinusa ucznia Efrema jako „nowe-

68 Ephraem Syrus, Hymni contra haereses I 12, tł. D. Cerbelaud, texte critique du CSCO, E. Beck, Hymnes contre les hérésies; Hymnes contre Julien vol I: Hymnes contre les hérésies I-XXIX, Paris 2017, s. 67. 
go Bar Daisana"69. Niestety, zupełnie nieznane są szczegóły jego odstępstwa od ortodoksji.

Interesujący obraz Edessy czasów Efrema wyłania się z jego syryjskiego Żywotu, mimo iż jest to późny, półlegendarny przekaz (według którego święty miał spędzić w Edessie większość życia od młodości, co jest dalekie od prawdy). Zachowały się tu dalsze echa kontaktu Efrema z bardesanitami. Według Żywotu odzyskał on od siostry Bar Daisana skażoną przez heretyka ewangelię, za co ta chciała wymóc korzyści seksualne ${ }^{70}$. Żywot wymienia także kilkukrotnie możnych Edessy, lecz jedynym przedstawionym $z$ imienia jest Abraham Kidunaja, który pod wpływem Efrema został ascetą i nawracał pogan ze wsi Kiduna. Efrem przekonuje bogaczy i elity miasta do pomocy ubogim w czasie głodu. Ci czynią to początkowo bardzo niechętnie, mimo iż - podkreśla Żywot - również są chrześcijanami ${ }^{71}$. Istnieje wyraźna przepaść między naśladowcami Efrema a zamożnymi mieszkańcami miasta, która wydaje się wykraczać poza zwykły konflikt między ascezą a bogactwem.

W Żywocie widać wyraźnie jeszcze jeden dysonans, który tak trapił Efrema. Z jednej strony Edessa zgodnie z opinią, którą miała już wówczas w niemal całym rzymskim świecie, jest wierna, mądra (jak to potwierdza rozmowa Efrema z kobietą na brzegu rzeki Daisan), otoczona klasztorami. Nieoczekiwanie jednak miasto w czasie przybycia Efrema zostaje opisane jako w przeważającej części pogańskie ${ }^{72}$. Młody (!) Efrem najmuje się do łaźni, stary mnich zaś pyta go, dlaczego ów brata się z poganami i czy wyraża chęć pozostania w świecie ${ }^{73}$. By poświęcić się Bogu, Efrem musi wyjść z Edessy.

Kolejne źródła wzmiankujące elity Edessy dotyczą dopiero episkopatu Rabbuli (412-435) i w dalszym ciągu dalekie są od przychylności. Rabbula, gorliwy biskup Edessy urodzony w Chalkis, podążając za tradycją ascezy, nawołuje do odrzucania ziemskiego majątku: „niech nie odciągają od Boga lśniące szaty i ornamenty", co podobnie jak w hymnie Efrema wydaje się być aluzją do stroju bogaczy ${ }^{74}$. Żywot Rabbuli wspomina możnych miasta i dość enigmatycznie tych, którzy szukają ucieczki w domach arystokra-

69 Za: J.P. Amar, The Syriac Vita Tradition of Ephrem the Syrian, CSCO 630, Lovanni 2011, s. XXIII.

70 Amar, The Syriac Vita Tradition of Ephrem the Syrian, s. XXVIII.

71 Vita Ephraemi 41A, tł. J.P. Amar, The Syriac Vita Tradition of Ephrem the Syrian, CSCO 630, Lovanni 2011, s. 96-98.

72 Vita Ephraemi 12, t1. J.P. Amar, s. 25 (wersje P i V; milczy o tym L).

73 Vita Ephraemi 13, tł. J.P. Amar, s. 26-27.

74 Vita Rabbulae 20, The Rabbula Corpus: Comprising ,, The Life of Rabbula”, His Correspondence, A Homily Delivered in Constantinople, Canons, and Hymns, 
tów. Kolejny fragment wzmiankuje „tych mających władzę”, pokonanych przez prawdomówność Rabbuli ${ }^{75}$. Te zawoalowane stwierdzenia pozwalają domyślać się nie tylko ziemskich grzechów, lecz jakichś podejrzanych zgromadzeń i skłonności ku herezji w bogatych domach. Jak słusznie zauważa autor opracowania o Rabbuli, Robert Doran (Stewards of the Poor. The Man of God, Rabbula, and Hiba in Fifth-Century Edessa, Kalamazoo 2006, s. xvii), biskup traktował możnych Edessy nieufnie. Żywot Rabbuli pokazuje, że ta niechęć była obopólna - wielu edesseńczykom nie podobały się ascetyczne idee ich duchowego zwierzchnika. Potwierdza się to, gdy Rabbula chce sprzedać złote i srebrne narzędzia liturgiczne. Mieszkańcy miasta proszą go, by tego zaniechał, gdyż należały one do ich przodków ${ }^{76}$. Należy w tym kontekście przypomnieć, że, jak dowodzi relacja pątniczki Egerii z końca IV wieku ${ }^{77}$, edesseńczycy zachowali dla zwiedzających pielgrzymów pałac Abgara i jego ogrody, posąg tego króla i jego syna Maenū, wreszcie - treść listu Jezusa w miejskich archiwach. Wszystkie te ,zabytki” związane były z elitami miasta, podobnie jak wspomniane wyżej drogocenne naczynia, najwidoczniej również taktowane jako rodzaj pamiątki po bogatych, pobożnych przodkach.

Wreszcie Żywot Rabbuli dostarcza nam chyba najciekawszej wzmianki mogącej wyjaśnić przyczyny milczenia źródeł o lokalnych elitach miasta: otóż podaje on, że nauka Bar Daisana kwitła wciąż w Edessie, dopóki Rabbula (działający prawie półtora wieku po Efremie) jej nie zwyciężył. Jest wprost powiedziane, że Bar Daisan ,zwabił możnych miasta swoimi pieśniami i chronił się nimi jak mocnymi ścianami”. Miał nadzieję, że potęga jego zwolenników pozwoli ugruntować mu herezję ${ }^{78}$. Trudno o wyraźniejsze potwierdzenie, że chrześcijaństwo Edessy jeszcze w pierwszej połowie $\mathrm{V}$ wieku było silnie

ed. R. Phenix - C.B. Horn, Atlanta 2017, s. 33: „Let not shining garments or polished ornaments weigh down the honor of your chastity".

75 Vita Rabbulae 36, The Rabbula Corpus, s. 53: „For who among the great ones of his city, or from among those who used to take refuge in the noble houses of those holding power in order to do evil, raised his head and uttered shrill sounds in [his] pomp and was not at once crushed by the heel of [Rabbula's] truthfulness so that he should regret that he was presumptuous?".

76 Vita Rabbulae 19, The Rabbula Corpus, s. 31: ,at the request of many he was prevented from doing any of this, since these were offerings of their forefathers".

77 Itinerarium Egeriae 19, 1-8, t1. M. McClure - C. Feltoe, The Pilgrimage of Etheria, London 1919, s. 30.

78 Vita Rabbulae 40, The Rabbula Corpus, s. 59: ,thus he also found the whole land of the house of the Edessenes entirely overgrown in the thickets of sin. For the evil doctrine of Bardaisan bloomed in Edessa prolifically until it was condemned by him and was conquered. Cursed by his cunning, Bardaisan first seized by the sweetness of his songs all the nobles oft he city, to be protected by them as though by strong walls". 
naznaczone naukami Bar Daisana. Nie wiemy jednak w jakim stopniu - być może przychylniejszy elitom biskup nie widziałby w nich heretyków.

Robert Doran (Stewards of the Poor, s. xvi) sądzi, że biskup Ibas (Hiba), który zastąpił Rabbulę, był bliższy poglądom elit. W przeciwieństwie do Rabbuli był to człowiek wykształcony w Edessie i prawdopodobnie $\mathrm{z}$ niej pochodzący, skoro w mieście mieszkał jego brat Euzebiusz ${ }^{79}$. Możliwe więc, że Ibas, podobnie jak Euzebiusz emeseński, był duchownym przedstawicielem lokalnych elit. $Z$ pewnością natomiast nie był mnichem i to właśnie mnisi i asceci z okolic miasta wystapili przeciw niemu najmocniej ${ }^{80}$. Potwierdza to, że chrześcijaństwo rozwijające się w Osroene wciąż pozostawało wyraźnie podzielone, nawet jeśli oficjalnych zarzutów herezji nie wyrażano wobec samej Edessy, a jedynie wobec enigmatycznych grup wewnątrz. Ascetyczne założenia syryjskiego chrześcijaństwa nie mogły być odleglejsze nie tylko od ziemskich przywiązań Bar Daisana, ale od całej kultury zarówno lokalnych, jak i rzymskich elit, kupców i uczonych północnej Mezopotamii. Mimo to związane z Kościołem źródła spoza Edessy postrzegają mnichów i mieszkańców miasta jako uzupełniającą się całość, co w wielu sytuacjach było dalekie od prawdy.

\section{Arystokracja Edessy a legenda o nauczaniu Addaja}

Należy teraz wrócić do najważniejszego ogniwa pamięci o lokalnych elitach Edessy, czyli do legendy o nawróceniu miasta. Bardzo prawdopodobną interpretację treści Nauki Apostoła Addaja przedstawił S. Brock (Eusebius and Syriac Christianity, s. 228) ${ }^{81}$ w ustępie, który warto tu przytoczyć w całości:

Drugim szczególnym obiektem zainteresowania Nauk Addaja są możni Edessy, z których kilku wymieniono jako pierwszych konwertytów, którzy odpowiedzieli na nauczanie Addaja [...] wygląda to, jakby autorzy [...] starali się propagować pogląd, że ich pogańscy przodkowie przeszli na chrześcijaństwo znacznie wcześniej niż miało to miejsce w rzeczywistości, a wyższe klasy Edessy wydały męczennika i wyznawcę na długo przed (historycznymi) męczeństwami Szmony, Gurii i Habbiba, którzy przybyli z okolicznych wiosek ${ }^{82}$.

79 Doran, Stewards of the Poor, s. XVI.

80 Doran, Stewards of the Poor, s. XVIII.

81 Do tezy przychyla się także R. Doran (Stewards of the Poor, s. XVII).

82 „A second special interest of the Teaching of Addai concerns the nobility of Edessa, several of whom are named as being the first converts to respond to Addai's preaching. [...] 
Nie należy jednak zapominać, że sama tradycja tego przekazu w wersji podanej przez Euzebiusza z Cezarei istniała wcześnie, już w pierwszych dziesięcioleciach IV wieku. Szybko została zaakceptowana przez ogół chrześcijańskiej ludności Edessy, weszła do historii kościelnej i dotarła nawet do odległych zakątków rzymskiego świata. Znała ją przybyła prawdopodobnie z Galii Egeria, która odwiedziła Edessę w 384 roku. Nie zauważyła ona w mieście oznak podziału - treść listu Jezusa była wyryta we wjazdowej bramie, po pamiątkach po Abgarze zaś oprowadzał ją sam biskup $^{83}$. A jednak główni beneficjenci legendy, którzy prawdopodobnie redagują nową jej wersję jeszcze w V wieku po Chrystusie, lokalne elity, są jeszcze za episkopatu Rabbuli oskarżane o kultywowanie herezji Bar Daisana.

Nie jest moim zadaniem w tym miejscu odtwarzanie nauki Bar Daisana i stopnia jej odstępstwa od ortodoksyjnego chrześcijaństwa. Ważniejszy dla rozważań pozostaje fakt, iż Bar Daisan był arystokratą na królewskim dworze zainteresowanym tradycjami astrologii i nauką, które to sfery były niejako oddzielone od samych praktyk wiary. Postawa taka, akceptowalna przed wielkimi prześladowaniami, była od czasów Konstantyna piętnowana coraz mocniej szczególnie na syryjskim Wschodzie, gdzie pojawiły się silne tendencje ascetyczne. Chrześcijaństwo w wersji Bar Daisana do tych założeń nie pasowało.

Nauka Addaja równieżjest daleka od ducha syryjskiego chrześcijaństwa Efrema i Rabbuli. Nawet w swojej wersji z V wieku w czasie, gdy wokół Edessy rozkwitają ascetyczne zgromadzenia i klasztory, Nauka Apostoła Addaja ukazuje w bardzo pozytywny sposób króla Abgara (który zostaje uzdrowiony, lecz nie rozdaje majątku, nie pości), arystokratów nawróconych, lecz wciąż bogatych. Dlaczego pobożni mnisi i pustelnicy, którzy w dodatku wrogo odnosili się do ówczesnych miejskich elit, zaakceptowali tę tradycję jako własną? Dlaczego nie atakował jej Efrem ani Rabbula?

Być może przyczyną była siła jej oddziaływania. Niewątpliwie już w IV wieku nikt nie podważał autentyczności konwersji Abgara za czasów Chrystusa. Starożytna świętość Edessy była tak oczywista, że Żywot Efrema tuszuje pamięć o pogańskich elementach obecnych w mieście. Bardzo możliwe, że legenda Addaja zyskała popularność i skonsolidowała mieszkańców miasta w czasie najazdów Szapura II, gdy Edessa kilkukrotnie musiała opierać się wrogim wojskom. Przed tymi wojnami Euzebiusz

It looks as if the authors [...] were seeking to promote the view that their pagan ancestors had converted to Christianity at a much earlier date than was in fact the case, and that the upper classes of Edessa had produced a martyr and a confessor long before the (historical) martyrdoms of Shmona, Guria and Habbib, who all came from surrounding villages".

83 Itinerarium Egeriae 19, 1-8, tł. M. McClure - C. Feltoe, s. 30. 
z Cezarei nie wzmiankuje jeszcze błogosławieństwa Jezusa dla miasta, wie o nim już Egeria, wyraźnie jest ono zapisane w Nauce Apostoła Addaja.

Podsumowując, można stwierdzić, że spuścizną dworu Abgarydów, która przetrwała upadek królestwa i była wciąż żywa w rzymskiej Edessie, były nauki Bar Daisana, pierwsze wpływy chrześcijaństwa w Edessie oraz przetrwanie części tradycji lokalnej arystokracji. Wydaje się, że te trzy elementy zazębiają się mocniej, niż to jest zazwyczaj przedstawiane, gdy patrzy się na każdy z nich oddzielnie. Elity miasta prawdopodobnie uległy znacznej romanizacji, jednak zachowały pamięć o królewskiej przeszłości miasta i aktywnie modelowały przekaz o swoich chrześcijańskich korzeniach. Jak ukazuje Żywot Rabbuli, także wpływy Bar Daisana musiały przetrwać w tych kręgach aż do V wieku. Nie można oczywiście wykluczyć, że pewne grupy bardesanitów zeszły na drogę kultywowania astrologii lub nawet silnie zwalczanego przez Efrema manicheizmu. Nie należy ich utożsamiać z całą warstwą możnych, gdyż brak na to dowodów oprócz rzucanych co jakiś czas oskarżeń kolejnych biskupów, że miejskie elity oddaliły się od ortodoksji. Już od czasów Efrema Bar Daisan był uważany za ciężkiego heretyka - sama znajomość jego nauk i kultywowanie podobnego stylu życia musiało budzić znaczne podejrzenia w oczach dążących do oczyszczenia wiary ascetycznych duchownych.

Paradoksalnie mimo znikomej obecności lokalnych elit w zachowanych źródłach, rozgłos, jaki Edessa zyskała w rzymskim świecie, zawdzięcza właśnie tej grupie bardziej niż Efremowi, Rabbuli czy syryjskim mnichom z pustyni. Legenda Addaja dała bowiem Edessie szczególnie miejsce wśród innych miast późnego Cesarstwa w dwóch aspektach: prestiżu religijnego i reputacji niezdobytej przez Persów twierdzy, chronionej obietnicą daną przez Chrystusa. Do tej samej tradycji należy także sławny potem w Bizancjum Mandylion. Być może przyczyn tak niejasnego pojawiania się kolejnych elementów opowieści o Addaju i Abgarze należy upatrywać właśnie w tym, że przechowywane były w kręgach traktowanych podejrzliwie przez inne nurty religijne Edessy, które w pewnym momencie zdobyły decydujący wpływ na narrację historyczną o mieście. Siła arystokratycznych chrześcijańskich tradycji była jednak tak duża, że zostały rozpowszechnione niejako ponad twórczością samego kręgu, z którego pochodziły. Dlatego należy zastanowić się, czy chrześcijańskie korzenie Edessy nie zostały zdefiniowane przez tych samych ludzi, których Efrem i Rabbula oskarżali o kultywowanie nauki Bar Daisana. 


\section{Christianization and Romanization of Elites in Roman Edessa}

(summary)

In the pre-Roman history of Edessa and Osrhoene, the role of the local elites gathered around the royal court, was clearly visible. By this time Edessean upper classes were strongly influenced with Iranian culture. In the process of incorporation of Osrhoene into Roman Empire, the elites of Edessa took over some Roman cultural models, and their representatives were part of the local administration already after the fall of the Abgarid dynasty in $242 \mathrm{AD}$. This article aims to trace references to the local aristocracy in sources concerning the history of Roman Edessa. Apparently this group continued to play a role after the transformation of the kingdom into a province, but remained in the shadow of dynamically developing ascetic Syrian Christianity. The elites of Edessa are associated with the figure of Bar Daisan, whose teachings survived at least until the 5 th century cultivated in a sect of Bardesanites. Although the sources mention the elites of Edessa occasionally and reluctantly, the most important tradition associated with them - the legend of the conversion of the city, preserved most detailed in Doctrina Addai - became the factor that made Edessa famous in the Roman world.

Keywords: Edessa; Christianization; local elites; Syriac culture; Bar Daisan

\section{Chrystianizacja i romanizacja elit w rzymskiej Edessie}

(streszczenie)

W przedrzymskiej historii Edessy i Osroene wyraźnie rysowała się rola lokalnej arystokracji skupionej wokół królewskiego dworu. Jej zwyczaje były silnie przesiąknięte kulturą irańską. Wraz ze stopniową utratą niepodległości elity miasta przejmowały do pewnego stopnia rzymskie wzorce kulturowe. Przedstawiciele ważnych edesseńskich rodów piastowali stanowiska w lokalnej administracji już po upadku dynastii Abgarydów w 242 roku po Chrystusie. Niniejszy artykuł ma na celu prześledzenie wzmianek na temat lokalnej arystokracji w źródłach dotyczących historii rzymskiej Edessy. Wskazują one, że warstwa ta nadal odgrywała pewną rolę po zamianie królestwa w prowincję, pozostając jednak w cieniu coraz prężniej rozwijającego się ascetycznego nurtu syryjskiego chrześcijaństwa. Z elitami Edessy związana jest postać Bar Daisana, którego nauki i sekta zwana bardesanitami przetrwały co najmniej do V wieku. Mimo iż zachowane źródła wzmiankują elity Edessy niechętnie i zdawkowo, najważniejsza z tradycji związanych z tym kręgiem - legenda o nawróceniu miasta przekazana w najpełniejszej formie w Doctrina Addai - stała się czynnikiem, który rozsławił Edessę w rzymskim świecie.

Słowa kluczowe: Edessa; chrystianizacja; lokalne elity; kultura syryjska; Bar Daisan 


\section{Bibliografia}

\section{Źródla}

Acta Martyrum Persarum, red. von O. Braun, Ausgewählte Akten Persischer Märtyrer, Kempten - München 1915.

Bardesanes, Liber legum regionum, t1. H.J.W. Drijvers, The Book of the Laws of Countries. Dialogue on Fate of Bardaisan of Edessa, Piscataway 2006.

Doctrina Addai, t1. G. Howard, The Teaching of Addai, Text and Translation, Ann Arbor 1981, tł. W. Witakowski, Nauka Apostoła Addaja: wstęp, przekład z języka syryjskiego, komentarz, STV 22/2 (1984) s. 181-213.

Egeria, Itinerarium Egeriae, tł. M. McClure - C. Feltoe, The Pilgrimage of Etheria, London 1919.

Ephraem Syrus, Hymni contra haereses, tł. D. Cerbelaud, texte critique du CSCO, E. Beck, Hymnes contre les hérésies; Hymnes contre Julien vol I: Hymnes contre les hérésies I-XXIX, Paris 2017.

Euphrates Papyri, tł. J. Teixidor, Deux documents syriaques du III siècle après J.-C., provenant du Moyen Euphrate, „Comptes-rendus de 1'Académie des Inscriptions et Belles-Lettres"134/1 (1990) s. 144-166.

Eusebius Caesariensis, Evangelicae Praeparationis Libri XV, tł. E.H. Gifford, London 1903, reprint Jacksonville Florida 2005.

Eusebius Caesariensis, Historia Ecclesiastica, tł. K. Lake, Loeb Classical Library 153, Cambridge 1926, tł. A. Caba, Euzebiusz z Cezarei, Historia kościelna, Kraków 2013. Hymnus Margaritae, The Hymn of the Pearl. The Syriac and Greek Texts with Introduction, Translations and Notes, tł. J. Ferreira, Sydney 2002.

Julius Africanus, Cesti, tł. W. Adler, Cesti: The Exant Fragments, Berlin - Boston 2012.

Martyrium SS. Guriae, Samonae et Abibi, tł. F. Burkitt, Euphemia and the Goth, London 1913.

Michael Syrus, Chronicon, tł. J.-B. Chabot, Chronique de Michel le Syrien, Patriarche Jacobite d"Antioche (1166-1199). Éditée pour la première fois et traduite en francais I-IV, Paris 1899-1901-1905-1910.

Socrates Scholasticus, Historia Ecclesiastica, tł. S. Kazikowski, Sokrates Scholastyk. Historia Kościoła, Warszawa 1972.

Sozomenus, Historia Ecclesiastica, tł. S. Kazikowski, Hermiasz Sozomen, Historia Kościoła, Warszawa 1989.

Vita Ephraemi, tł. J.P. Amar, The Syriac Vita Tradition of Ephrem the Syrian, CSCO 630, Lovanni 2011.

Vita Rabbulae, tł. The Rabbula Corpus: Comprising „The Life of Rabbula”, His Correspondence, A Homily Delivered in Constantinople, Canons, and Hymns, ed. R. Phenix - C.B. Horn, Atlanta 2017. 


\section{Opracowania}

Adler W., The Kingdom of Edessa and the Creation of a Christian Aristocracy, w: Jews, Christians and the Roman Empire. The Poetics of Power in Late Antiquity, red. N.B. Dorhman - A. Yoshiko Reed, Philadephia 2013, s. 43-62.

Blanco-Pérez A., Nomenclature and Dating in Roman Asia Minor: (M.) Aurelius/a and the 3rd Century AD, ZPE 199 (2016) s. 271-293.

Brock S., Eusebius and Syriac Christianity, w: Eusebius, Christianity, and Judaism, red. H.W. Attridge - G. Hata, Detroit 1992, s. 212-234.

Doran R., Stewards of the Poor. The Man of God, Rabbula, and Hiba in Fifth-Century Edessa, Kalamazoo 2006.

Drijvers H.J.W. - Healey J.F., The Old Syriac Inscriptions of Edessa and Osrhoene, Texts, Translations and Commentary, Leiden 1999.

Drijvers J.W., The Protonike Legend, the Doctrina Addai and Bishop Rabbula of Edessa, VigCh 51/3 (1997) s. 298-315.

Edwell P., Between Rome and Persia: the middle Euphrates, Mesopotamia and Palmyra under Roman control, New York 2008.

Gnolli T., The Interplay of Roman and Iranian Titles in the Roman East, 1st-3rd Century A.D., Wien 2007.

von Gudchmid A., Untersuchungen über die Geschichte des Königreichs Osroëne, St. Petersbourg 1887.

Hagedorn D., ,Marci Aurelii” in Ägypten nach der Constitutio Antoniniana, „Bulletin of the American Society of Papyrologists" 16 (1979) s. 47-59.

Harnack D., Partische Titel, vornehmlich in den Inschriften aus Hatra. Ein Beitrag zur Kentniss des parthischen Staates, w: Geschichte Mittelasiens in Altertum, red. F. Altheim - R. Stiehl, Berlin 1970, s. 492-549.

Ilski K., Chrzest Konstantyna Wielkiego, w: Teologia i liturgia chrztu od starożytności chrześcijańskiej do czasów nowożytnych, red. A. Wyrwa - J. Górecki, Poznań 2015, s. 137-152.

Konrad M., The Client Kings of Emesa. A Study of Local Identities in the Roman East, „Syria” 94 (2017) s. 261-295.

Ross S.K., The Last King of Edessa: New Evidence from the Middle Euphrates, ZPE 97 (1993) s. 187-206.

Ross S.K., Roman Edessa. Politics and Culture on the Eastern Fringes of the Roman Empire, 114-242 CE, London 2001.

Segal J., Edessa, The Blessed City, London 1970.

Segal J., Abgar, w: Encyclopaedia Iranica, t. I/2, red. E. Yarshater, London 1982, s. 210-213.

Sommer M., Roms orientalische Steppengrenze: Palmyra, Edessa, Dura-Europos, Hatra. Eine Kulturgeschichte von Pompeius bis Diocletian, Stuttgart 2005. 
Teixidor J., Deux documents syriaques du III siècle après J.-C., provenant du Moyen Euphrate, „Comptes-rendus de l'Académie des Inscriptions et Belles-Lettres” 134/1 (1990) s. 144-166.

The Excavations at Dura-Europos Conducted by Yale University and the French Academy of Inscriptions and Letters. Final Report V, Part I. The Parchments and Papyri, red. Welles C. - Fink R. - Gilliam J., New Haven 1959.

Uciecha A., Wattki polemiczne w pismach Afrahata i św. Efrema, w: Chrześcijaństwo antyczne, red. J. Drabina, Kraków 2006, s. 114-126.

Walker J., The Legend of Mar Qardagh: Narrative and Christian Heroism in Late Antique Iraq, Berkeley 2006.

Webster J., Creolizing the Roman Provinces, „American Journal of Archaeology” 105/2 (2001) s. 209-225.

Winn R.E., Eusebius of Emesa. Church and Theology in the Mid-Fourth Century, Washington 2011.

Winkelmann S., Materialen des SFB „Differenz und Integration” Heft IV, Katalog der parthischen Waffen und Waffenträger aus Hatra, Halle 2004.

Winkelmann S., Waffen und Wafferträger auf Partischen Münzen, „Parthica” 8 (2006) s. 131-152.

Winkelmann S., Partherzeitliche Waffenträger in Edessa und Umgebung, w: Edessa in hellenistisch-römischer Zeit: Religion, Kultur und Politik zwischen Ost und West; Beiträge des Internationalen Edessa-Symposiums in Halle an der Saale, 14. - 17. Juli 2005, red. J. Tubach - C. Rammelt - L. Greisiger, Würzburg 2009, s. 313-366.

Yon J.-B., La romanisation de Palmyre et des villes de l'Euphrate, „Annales. Histoire, Sciences Sociales" 59/2 (2004) s. 313-336. 